\title{
ОСОБЛИВОСТІ РЕАЛІЗАЦІЇ ПРИНЦИПУ СУВЕРЕННОЇ РІВНОСТІ ДЕРЖАВ В СУЧАСНОМУ МІЖНАРОДНОМУ ФІНАНСОВОМУ ПРАВІ
}

Постановка проблеми. Сучасною ознакою міжнародного спільноти є, насамперед, впорядкованість його структури, відносин між його компонентами, що взаємопов'язані між собою. Фактори взаємодії та взаємозалежності отримують свій вираз у вигляді загальних основ правової міжнародної системи, які створюють правову єдність особливого характеру та в рівній мірі необхідні та прийнятні для всіх держав з різними економічними системами, ідеологією, рівнем розвитку тощо. Системоутворюючим чинником та основою будь-якої системи права виступають принципи, які закріплюють вихідні, керівні положення загального характеру, що відносяться до всіх або більшості норм галузі та права в цілому [1, с. 126-127].

В системі міжнародного фінансового права, як та в будь-якій галузі міжнародного права, основні принципи міжнародного права займають основоположне значення. Серед них особливе місце займає принцип суверенної рівності держав, в якому закладена основа фундаментальної ідеї міжнародного права - спілкування рівноправних держав [2, с. 46]. В умовах економічної глобалізації та взаємозалежності, керуючись національними інтересами у сфері фінансів, держави намагаються досягти власних цілей шляхом співробітництва як у форматі дво- та багатосторонніх міжнародних договорів, так та в рамках міжнародних фінансових організацій. Правовий аналіз міжнародних актів, що закріплюють правила міждержавного спілкування держав у фінансовій сфері, свідчить про наявність в них положень, які ставлять в нерівне положення держави (наприклад, преференційні режими для окремих країн, правила «зваженого» голосування в міжнародних фінансових організаціях тощо). Це обумовлює необхідність більш детального наукового дослідження реалізації принципу суверенної рівності на практиці міждержавних фінансових відносин.

Аналіз останніх досліджень та публікацій. В міжнародно-правовій науці, як західній, так та в межах пострадянського простору, в силу відносно малої уваги з боку науковців до міжнародного фінансового права як галузі міжнародного публічного права питання принципів даної галузі майже не досліджувалось. Торкались даного питання у своїх працях Л.Л. Лазебник [3], В.М. Шумілов [4]. Значно більша увага в міжнародно-правовій літературі приділена принципам міжнародного економічного права. Дану проблематику вивчали М.М. Богуславский, Г.Ю. Бувайлик, Г.М. Вельямінов, С.А. Войтович, Л.А. Комарова, Б.І. Кучер, Г.І. Тункин, В.Г. Шкода, В.М. Шумілов, В.Ф. Опришко, О.О. Харчук та інші.

Принцип суверенної рівності держав в міжнародному праві досліджували С.Б. Крилов, О.О. Моїсєєв, Г.І. Тункін, М.О. Ушаков, В. Алєксандріков, Н.В. Захарова, 3.М. Кафаров, О.В. Пирогов, Л.А. Алексідзе, Р.А. Каламкарян, І.І. Лукашук, А.М. Талалаєв, О.І. Тіунов, С.В. Черніченко, Л.М. Шестаков, Н.В. Кирилюк.

Метою статті є дослідити особливості реалізації принципу суверенної рівності держав в сучасному міжнародному фінансовому праві. 
Результати дослідження. Історично принцип суверенної рівності сформувався та розвивався на основі двох нормативних засад: поваги суверенітету всіх держав та визнання їх рівноправності у міжнародних відносинах $[2$, с. $45 ; 5$, с. $116 ; 6$, с. 197 ; 7, с. 46]. Обидві складові вважаються базовими в інституті міжнародної правосуб'єктності щодо визначення статусу держави як суб'єкта міжнародного права [8, с. 222]. Відповідно до принципу суверенної рівності держави повинні поважати суверенну рівність та своєрідність один одного та всі права, що притаманні їх суверенітету та ним охоплені, до яких входить, зокрема, право держави на юридичну рівність, на територіальну цілісність, на свободу та політичну незалежність, на вибір та розвиток своїх політичних, соціальних, економічних та культурних систем, на встановлення своїх законів та адміністративних правил, на здійснення відносин з іншими державами на свій розсуд, на зміну своїх державних кордонів, на право належати до міжнародних організацій, бути учасниками двосторонніх та багатосторонніх міжнародних договорів, право на нейтралітет (Прикінцевий акт НБСЄ від 1975 р. [9].).

Принцип суверенної рівності держав у сфері міжнародних фінансових відносин отримав закріплення в Хартії економічних прав та обов'язків держав 1974 року. Відповідно до статті 10 Хартії «всі держави юридично рівноправні та як рівноправні члени міжнародного спільноти мають право повністю та ефективно брати участь в міжнародному процесі прийняття рішень для врегулювання світових економічних, фінансових та валютних проблем <...>» [10]. Декларація про встановлення нового міжнародного економічного порядку від $1974 \mathrm{p}$. серед принципів, на яких базується новий міжнародний економічний правопорядок, на першому місці зазначає такий основний принцип міжнародного права як суверенна рівність держав. Також, Декларація закріплює повний невіддільний суверенітет кожної держави над всією економічною діяльністю та своїми природними ресурсами, для охорони яких кожна держава має право здійснювати контроль (п. 4.е) [11].

Принцип суверенної рівності держав в міжнародному фінансовому правопорядку означає рівну правосуб'єктність держав в міжнародних фінансових відносинах та суверенітет держави щодо національних фінансів та фінансової системи. Держава як суб'єкт міжнародного фінансового правопорядку відповідно до фінансового державного суверенітету має право самостійно та незалежно здійснювати свою зовнішню та внутрішню фінансову політики, реалізовуючи тим самим свій зовнішній та внутрішній фінансовий державний суверенітет.

На перший погляд дотримання принципу суверенної рівності держав в сучасному міжнародному фінансовому правопорядку не викликає сумнівів. Проте, окремі аспекти реалізації даного принципу в практиці міжнародних фінансових відносин та, навіть більше, деякі правові положення міжнародних актів змушують ставити під сумнів його «безумовне» дотримання в міжнародному фінансовому правопорядку.

Серед переліку принципів, що виступають основою нового міжнародного економічного порядку, Декларація закріплює принцип «забезпечення сприятливих умов для передачі фінансових коштів країнам, що розвиваються» (п. 4.о) [11]. Стаття 22 Хартії економічних прав та обов'язків держав 1974 р. закріплює за розвиненими країнами зобов'язання сприяти збільшенню чистого притоку фінансових коштів 3 
офіційних джерел в країни, що розвиваються [10]. Звичайно, преференційний режим, як та інші види режимів, мають право на існування в міждержавних економічних взаємовідносинах, але в даному випадку підкреслюється саме «невзаємний режим» їх надання (п. 4.n Декларації, ед.19 Хартії). Такого роду розмежування правового статусу суб'єктів міжнародного фінансового правопорядку справляє враження як порушення рівності між державами, а також нівелювання принципу економічної вигоди - основного принципу ринкової економіки.

Проте, аналіз причин закріплення такої нібито «нерівності» держав та його формального виразу в міжнародних правових актах дає підстави вважати, що між закріпленим принципом преференцій та принципом суверенної рівності держав системних зв'язків та узгодженості не порушено. По-перше, закріплення преференційних режимів в таких документах як Хартія та Декларація вже з формальних причин свідчить про його юридичну підпорядкованість принципу суверенної рівності держав, що закріплений в Статуті ООН. По-друге, форма викладення принципу надання країнам преференцій та невзаємного режиму викладена у такій словесній формі, яка більше схожа на звернення (або заклик) до держав здійснювати такі преференції. Відсутність будь-якого натяку на імперативність даної норми обумовлена вживанням замість слів «застосовувати», «здійснювати» слова «прагнути» (ед. 22 Хартії) та, що важливо, «по мірі можливостей» держав (п. 4. n Декларації). По-третє, принцип надання преференцій країнам, що розвиваються, насправді не порушує принцип економічної вигоди. Захист фінансової незалежності та сприяння розвитку фінансовим системам країн, що розвиваються, 3 боку міжнародної спільноти обумовлений не тільки міркуваннями справедливості, але й, насамперед, розумінням економічної вигоди в майбутньому. В силу швидких темпів глобалізації в міжнародній фінансовій системі, яка спричинила взаємозалежність як валют держав, так та національних фінансових систем в цілому, фінансова криза в одному регіоні світу в силу сучасних технологічних можливостей фінансових операторів швидко поширюється на світову фінансову систему. Це потребує не тільки тісної та узгодженої співпраці між країнами в напрямку протидії фінансовим кризам. Міжнародною спільнотою визнано, що процвітання світової спільноти загалом залежить від процвітання його складових частин - всіх країн. Стабільність всіх національних фінансових систем, включаючи країни, що розвиваються, є економічно вигідною (в глобальному масштабі) всім країнам світу, включаючи економічно розвиненим.

Наступним дискусійним моментом стосовно дії принципу суверенної рівності держав, зокрема в частині їх суверенного права самостійно та незалежно здійснювати свою зовнішню та внутрішню фінансову політики, є виконання державами положень правових актів міжнародних фінансових організацій. Делегування країнами своїх суверенних повноважень у фінансовій сфері в рамках міжнародних фінансових організацій, ставить під питання повноту суверенних прав таких держав у фінансовій сфері.

В контексті з’ясування даного питання, слід зазначити, що держави добровільно наділяють органи цих організацій правом приймати рішення у сфері фінансів відповідно до статутних цілей та завдань організації з метою підтримання безпечного 
функціонування світової фінансової системи та своїх національних систем. В такий спосіб держави захищають свої національні фінансові системи від різного роду фінансових криз. Навіть більше, передаючи частину своєї компетенції міжнародним організаціям, держави не обмежують свій суверенітет, а реалізовують своє суверенне право укладати міжнародні договори з іншими суб'єктами міжнародного права. Міжнародні зобов'язання не зменшують універсальної правоздатності держави, а обмеження дій держави, що випливає з їі міжнародно-правових зобов'язань, $€$ не обмеженням державного суверенітету, а обмеженням правоздатності держави, тобто обмеженням у здійсненні певних суверенних прав. Тому, в даному випадку, в рамках міжнародних організацій та під час укладення міжнародних договорів може здійснюватись лише обмеження суверенних прав держави, а не ї̈ суверенітету [12, с. 164].

В контексті дотримання міжнародних принципів визнання державного суверенітету та невтручання у внутрішні справи під час співпраці країн в рамках міжнародних фінансових організацій слід підкреслити наступні правові аспекти такого обмеження суверенних прав. По-перше, воно є добровільним - країни, користуючись своїм суверенним правом приймати подібні рішення, дають згоду на нього. По-друге, це обмеження не $€$ постійним (воно може бути та тимчасовим), оскільки країна завжди вправі зупинити своє членство в міжнародній фінансовій організації. М.А. Корольов зазначає, що наднаціональність у чистому вигляді неможлива, оскільки до поки країни-члени наднаціонального утворення зберігають свій суверенітет, вони можуть в будь-який час зупинити своє членство в ньому, причому відібрати таке право неможливо [13, с. 9]. По-третє, країна не втрачає повністю всі повноваження по тих питаннях, щодо яких суверенні права обмежені, проте ії повноваження в певній мірі підпорядковані. Країна добровільно делегує свої права міжнародній фінансовій організації, не втрачаючи при цьому власної компетенції за делегованими питаннями. По-четверте, ціль, заради якої країна погоджується на обмеження своїх суверенних прав в окремих фінансових питаннях, відповідає її інтересам та сприяє розвитку національної фінансової системи. Отже, в міжнародному фінансовому правопорядку відбувається «переливання» певних суверенних фінансових прав держав в міжнародні фінансовій інституції з метою централізованої та більш професійної координації дій держав в міжнародних фінансових відносинах.

Не менш дискусійним питанням в контексті реалізації принципу суверенної рівності в міжнародному фінансовому правопорядку є принцип «зваженого» голосування країнами-членами в міжнародних фінансових організаціях, при якому кількість голосів країни-члена залежить від зазначених в статутних документах критеріїв. Наприклад, в МВФ такими критеріями виступають - об'єм квоти держави-члена в статутному капіталі Фонду (за кожні 100 тис. СПЗ додається 1 голос), об’єм чистого продажу валюти держави-члена з загальних ресурсів Фонду (за кожні 400 тис. СПЗ додається 1 голос), об'єм чистих закупок Фондом валюти держави-члена (за кожні 400 тис. СПЗ віднімається 1 голос) [14]. Цілком очевидно, що при таких критеріях оцінки «ваги» голосів країн-членів менш потужні у фінансовому відношенні держави завжди будуть мати порівняно менше голосів під час голосування та це ставить держави в нерівне положення. 
Вирішення даної дискусії лежить у двох площинах: економічній та правовій. З економічної точки зору, отримання державами прав при голосуванні пропорційно їх фінансовим внескам є економічно обгрунтованим, оскільки при такому розподілі голосів країни ризикують під час прийняття певного рішення пропорційно своїм внескам (подібний принцип голосування закладений у фінансових установах, активи яких сформовані нерівними долями учасників, наприклад, власників акцій тощо). Враховуючи взаємозв'язок національних валют держав та їх фінансових систем, інтереси більш фінансово потужних країн в кількісному відношенні більше зазнають шкоди від прийняття хибного в економічному сенсі рішення.

3 правової точки зору підтвердженням не порушення правилами «зваженого голосування» в міжнародних фінансових організаціях принципу суверенної рівності держав слугує стаття 10 Хартії, згідно з якою «всі держави юридично рівні та як рівноправні члени міжнародної спільноти мають право повністю та ефективно брати участь в міжнародному процесі прийняття рішень для врегулювання світових фінансових та валютних проблем, серед іншого, через посередництво відповідних міжнародних організацій, відповідно до їх чинних правил, та справедливо користуватись вигодами, що випливають з цього» [10]. Стаття, закріплюючи право держав на рівних умовах брати участь у розв'язанні міжнародних фінансових питань, включає такий спосіб як співпраця країн в рамках міжнародних організацій, але відповідно до чинних правил організацї. Навіть більше, статути міжнародних фінансових організації являють собою багатосторонні міжнародні договори, положення яких відповідають основним принципам міжнародного права. В противному випадку, згідно зі статтею 53 Віденської конвенції про право міжнародних договорів від 1969 року такі договори були б визнані нікчемними [15]. Можна було б припустити, що оскільки Конвенція не має зворотної дії (ст. 4), вона не може застосовуватись до Статутів МВФ, МБРР, які прийняті в 1945 році. Проте, після 1969 року було успішно засновано не одну міжнародну фінансову організацію, голосування в яких здійснюється за аналогічним принципом «зваженого голосування», що підтверджує його відповідність принципу суверенної рівності держав. Так, згідно зі статтею 29 Угоди про заснування Європейського банку реконструкції та розвитку від 1990 року «число голосів, на яке має право кожний член, дорівнює кількості акцій в статутному капіталі Банку, на яку він підписався <... > [16].

Зазначене свідчить, що, з одного боку, міжнародні фінансові організації виступають як банки, які надають кредити під відсотки, тобто діють як суб'єкти господарювання. В цій площині діяльності принцип «зваженого» голосування є абсолютно доцільним. Проте, з іншого боку, на міжнародні фінансові організації (особливо МВФ) покладаються та інші функції, що пов'язані з підтримкою стабільності всієї міжнародної фінансової системи, сприяння економічній стабільності в усіх країнах тощо. «Зважена» участь держав-членів при вирішенні таких важливих для міжнародної спільноти питань не дає їм рівного впливу при голосуванні. Навіть у випадку стрімкого економічного зростання, країнам, які мають малу територію, важко досягнути рівних з великими країнами «ваги» голосів. «Зважений» механізм голосування a priori не забезпечує державам рівних вихідних потенціалів. В силу зазначених особливостей реалізації принципу суверенної рівності держав 
на практиці відбуається ситуація різних юридичних можливостей. Як слушно зазначає В.Г. Буткевич, коли йдеться про рівність держав, то слід мати на увазі юридично рівні потенційні можливості щодо розв'язання питань у неврегульованих сферах міжнародних відносин, які де-ракто далеко не рівнозначні [8, с. 225]. На наш погляд, в міжнародному фінансовому правопорядку відбувається унормована на міжнародному рівні диференціація юридичних можливостей держав, в залежності від їх фінансової потужності, брати участь у розвязанні міжнародних фінансових питань в рамках міжнародних фінансових організацій.

Висновок. Принцип суверенної рівності держав в міжнародному фінансовому правопорядку полягає в рівній правосуб'єктності держав в міжнародних фінансових відносинах та суверенітеті держави щодо національних фінансів та фінансової системи. Специфіка міжнародних фінансових правовідносин в контексті дотримання даного принципу полягає в таких особливостях його реалізації:

1. Закріплення в міжнародних актах положень щодо надання країнам, що розвиваються, преференцій у фінансовій сфері на «невзаємній» основі не порушує принципу суверенної рівності, оскільки: дана норма не є імперативною, а є стратегічно-бажаним орієнтиром дій для держав в силу їх можливостей; стабільність всіх національних фінансових систем, включаючи країни, що розвиваються, є економічно вигідними всім країнам світу, включаючи економічно розвинені;

2. Делегування країнами своїх суверенних фінансових повноважень міжнародним фінансовим інституціям не являється обмеженням свого фінансового суверенітету, а навпаки - реалізацією свого суверенного права на укладення міжнародних договорів. Обмеження суверенних прав держав у фінансовій сфері в рамках членства у міжнародних фінансових організаціях здійснюється на умовах добровільності, тимчасовості, частковості (країна не втрачає всі повноваження по тих питаннях, щодо яких суверенні права обмежені), обмеження здійснюється у фінансових інтересах держави;

3. Правило «зваженого» голосування в міжнародних фінансових організаціях, при якому кількість голосів країни-члена залежить від зазначених в статутних документах економічних критеріїв, не дає їм рівного впливу при прийнятті рішень. В міжнародному фінансовому правопорядку відбувається унормоване на міжнародному рівні диференціювання потенційних юридичних можливостей держав (в залежності від їх фінансових потужностей) щодо розв’язання важливих фінансових питань в рамках міжнародних фінансових організацій.

\section{Jimepamypa:}

1. Сырых В.М. Теория государства и права : Учебник. Москва : Юридический Дом «Юстицинформ», 2001. $592 \mathrm{c.}$

2. Курс международного права : Основные принципы международного права : в 7 т. / рецензенты Г.П. Жуков, Д.И. Фельдман, В.Н. Лихачев. Москва : Наука, 1989-1993. Т. 2. 1989. 240 с.

3. Лазебник Л.Л. Міжнародне фінансове право : навч. пос. Київ : Центр учбової літератури, 2008. 312 c.

4. Шумилов В.М. Международное финансовое право. Учебник. 2-е изд., перераб. и доп. Москва : Междунар.отношения, 2011. 328 с.

5. Международное право : учебник / Г.И. Тункин, Д.И. Фельдман, И.И. Лукашук и др. Москва : Юрид. лит., 1982.568 с. 
6. Международное право : учебник / Л.А. Анисимов, К.Г. Борисов, Э. . Кривчикова и др. Москва : Международные отношения, 2000. 714 с.

7. Тункин Г.И. Право и сила в международной системе : монография. Москва : Международные отношения, $1983.200 \mathrm{c}$.

8. Буткевич В.Г., Мицик В.В., Задорожній О.В. Міжнародне право. Основи теорї : Підручник / за ред..В.Г.Буткевича. Київ : Либідь, 2002, 608 с.

9. Заключний акт Наради 3 безпеки та співробітництва від 01.08.1975p. URL: https://zakon.rada.gov.ua/laws/card/994_055/ find?text=\% E2\% FB\% E3\% EE

10. Хартія економічних прав та обов'язків держав від 12 грудня 1974 року. URL: http://zakon3.rada.gov.ua/laws/show/995_077

11. Резолюція 3201 (S-VI) від 1 травня 1974 року, яка закріплює Декларацію про встановлення нового міжнародного економічного порядку. URL: http://zakon3.rada.gov.ua/laws/show/995_339

12. Державний суверенітет в умовах європейської інтеграції: монографія / Ю.П. Битяк, І.В. Яковюк, С.Г. Серьогіна та ед.; за ед... Ю.П. Битяка, І.В. Яковюка. Київ : Ред.журн. «Право України», 2012. $336 \mathrm{c}$.

13. Королев М.А. Наднациональность с точки зрения международного права. Московский журнал международного права. 1997. № 2. С. 3-20.

14. Статті Угоди Міжнародного валютного фонду від 22 липня 1944 року. URL: http://zakon2.rada.gov.ua/laws/show/995_921/page

15. Віденська конвенція про міжнародні договори від 23 травня 1969року. URL: https://zakon.rada.gov.ua/laws/card/995_118

16. Угода про заснування Європейського банку реконструкції та розвитку від 29 травня 1990 року

\section{Анотація}

Вайцеховська О.Р. Особливості реалізації принципу суверенної рівності держав в сучасному міжнародному фінансовому праві. - Стаття.

У статті розглянуто сутність принципу суверенної рівності держав в міжнародному фінансовому праві. На підставі аналізу положень міжнародних документів, що закріплюють принципи функціонування міжнародного фінансового правопорядку, проаналізовано особливості реалізації принципу суверенної рівності держав в практиці сучасних міждержавних фінансових відносин.

Ключові слова: принцип суверенної рівності держав, міжнародне фінансове право, міжнародний фінансовий правопорядок, преференційний режим, «зважене» голосування, міжнародна фінансова організація.

\section{Аннотация}

Вайцеховская О. Р. Особенности реализации принципа суверенного равенства государств в современном международном финансовом праве. - Статья.

В статье рассмотрена суть принципа суверенного равенства государств в международном финансовом праве. На основе анализа правовых норм международных документов, закрепляющих принципы функционирования международного финансового правопорядка, проанализированы особенности реализации принципа суверенного равенства государств в практике современных межгосударственных финансовых отношений

Ключевые слова: принцип суверенного равенства государств, международное финансовое право, международный финансовый правопорядок, преференционный режим, «взвешенное» голосование, международная финансовая организация.

\section{Summary}

Vaitsekhovska $O$. R. Peculiarities of implementation of the principle of sovereign equality of states in modern international financial law. - Article.

The paper examines the essence of the principle of the sovereign equality of states in international financial law. Peculiarities of the implementation of the principle of the sovereign equality of states in the practice of modern interstate financial relations are analyzed based on the study of the provisions of international instruments that enshrine the principles of functioning of the international financial legal order.

Key words: principle of the sovereign equality of states, international financial law, international financial legal order, preferential treatment, "weighted" voting, international financial organization. 